\title{
Arctic climate sensitivity to local black carbon
}

\author{
Mark G. Flanner ${ }^{1}$ \\ Received 18 June 2012; revised 4 January 2013; accepted 6 January 2013; published 26 February 2013.
}

[1] Recent attention has focused on the impact of black carbon (BC) on Arctic climate.

Here, idealized equilibrium climate experiments are conducted to explore the dependence of Arctic temperature change on the altitude and season of local $\mathrm{BC}$ forcing. $\mathrm{BC}$ residing in the lowest atmospheric layer produces very strong Arctic warming per unit mass and forcing $\left[2.8 \pm 0.5 \mathrm{~K}\left(\mathrm{~W} \mathrm{~m}^{-2}\right)^{-1}\right]$ because of low cloud and sea-ice feedbacks that amplify both summer and winter warming. BC operating only within Arctic snow and sea-ice also effectively warms the surface, but forcings at 400-750 mbar and 210-250 mbar cause weak surface warming and cooling, respectively, despite increasing atmospheric moist static energy. This is a consequence of stable atmospheric conditions in the Arctic limiting vertical mixing, and of higher-altitude $\mathrm{BC}$ reducing surface insolation, increasing stability and summer low-cloud cover, and decreasing poleward energy transport. The current simulated distribution of Arctic atmospheric BC slightly cools the surface, supporting an earlier study, while local atmospheric and cryosphere-deposited $\mathrm{BC}$ warms the Arctic with a sensitivity of $+0.5 \pm 0.4 \mathrm{~K}\left(\mathrm{~W} \mathrm{~m}^{-2}\right)^{-1}$. By season, April-May tropospheric BC induces the greatest mass-normalized Arctic warming $\left[0.18 \mathrm{~K}(\mathrm{Gg} \mathrm{yr})^{-1}\right]$ because high insolation and surface albedo facilitate large specific forcing during this season. Forcing efficacy, however, increases with summer progression because of decreasing atmospheric stability, leading to a narrow range of mass-normalized response with season. Although limited by exclusion of aerosol indirect effects, changes in ocean heat transport and forcing by co-emitted species, these experiments show that Arctic climate response is sensitive to the vertical distribution and deposition efficiency of $\mathrm{BC}$ reaching the Arctic.

Citation: Flanner, M. G. (2013), Arctic climate sensitivity to local black carbon, J. Geophys. Res. Atmos., 118, 1840-1851, doi:10.1002/jgrd.50176.

\section{Introduction}

[2] Climate modeling studies indicate that Arctic climate warms from global emissions of black carbon (BC), which absorbs solar energy in the atmosphere and snowpack [e.g., Hansen and Nazarenko, 2004; Jacobson, 2004; Hansen et al., 2005; Flanner et al., 2007, 2009; Koch et al., 2009a; Shindell and Faluvegi, 2009; Jacobson, 2010; Shindell et al., 2012]. Such findings have helped motivate studies that (1) explore mitigation of Arctic warming via $\mathrm{BC}$ and other short-lived pollutants in the Arctic [e.g., Quinn et al., 2008], (2) identify sources, radiative forcing contributions, and transport mechanisms of $\mathrm{BC}$ reaching high latitudes [e.g. Koch and Hansen, 2005; Stohl, 2006; Reddy and Boucher, 2007; Koch et al., 2007; Shindell et al., 2008; Hegg et al., 2009; Warneke et al., 2010; Hirdman et al., 2010; Gong et al., 2010; Liu et al., 2011; Wang et al.,

\footnotetext{
${ }^{1}$ Department of Atmospheric, Oceanic and Space Sciences, University of Michigan, Ann Arbor, Michigan, USA.

Corresponding author: M. G. Flanner, 2455 Hayward St., University of Michigan, Ann Arbor, MI 48109-2143, USA. (flanner@umich.edu)

(C)2013. American Geophysical Union. All Rights Reserved.

2169-897X/13/10.1002/jgrd.50176
}

2011; Bond et al., 2011; Skeie et al., 2011], and (3) conduct and analyze measurements of Arctic BC and its radiative impact [e.g., Sharma et al., 2006; McConnell et al., 2007; Stone et al., 2008; Forsström et al., 2009; Eleftheriadis et al., 2009; Doherty et al., 2010; Brock et al., 2011].

[3] One recent study conducted with the GISS-ER climate model, however, indicates that the Arctic surface slightly cools in response to BC in the Arctic atmosphere, caused by reduced poleward energy flux and surface insolation, while warming in response to $\mathrm{BC}$ forcing exerted in the northern midlatitudes and tropics [Shindell and Faluvegi, 2009]. This finding has important implications for $\mathrm{BC}$-targeted strategies to mitigate Arctic climate change and thus warrants additional study. Here, idealized experiments are conducted with the Community Earth System Model (CESM) to (1) explore Arctic climate sensitivities and feedback processes resulting from a wider range of local BC forcings than explored by Shindell and Faluvegi [2009], including those exerted in snow and sea-ice, and at different altitudes and seasons; and (2) evaluate the robustness of conclusions from Shindell and Faluvegi [2009] regarding Arctic surface temperature response to current simulated distributions of Arctic and extra-Arctic atmospheric BC. Objective 1 is approached with fixed aerosol absorption optical depth (AAOD) experiments that produce clearly 
defined sensitivities and can be easily reproduced with other climate models, while objective 2 applies a prognostic aerosol model to simulate spatially and temporally varying $\mathrm{BC}$ distributions. This study builds on previous modeling studies of climate response to global BC forcing exerted at different altitudes [e.g., Turco et al., 1983; Hansen et al., 1997; Penner et al., 2003; Hansen et al., 2005; Robock et al., 2007; Ban-Weiss et al., 2011] and Arctic response to local and remote aerosol forcing [e.g., MacCracken et al., 1986; Rinke et al., 2004; Shindell, 2007; Robock et al., 2008; Shindell and Faluvegi, 2009; Goldenson et al., 2012].

[4] A more comprehensive picture of the variability in Arctic temperature response to different Arctic BC forcings aids in interpreting the relative impacts of (1) remote sources, often reaching the Arctic at high altitudes along isentropic surfaces [Koch and Hansen, 2005; Stohl, 2006], (2) sources emitted within the polar dome, transported to the Arctic at lower altitude and more likely to deposit to Arctic snow and ice, and (3) local sources emitted into the Arctic boundary layer, likely to increase with rising commercial activity, shipping, and energy extraction in the Arctic [e.g., Corbett et al., 2010]. These studies also aid in interpreting the influence of emissions reaching the Arctic during different seasons, notably those from agricultural burning, domestic wood burning, and forest fires [e.g., Warneke et al., 2010]. Actual climate changes from these activities depend, however, on the full forcing life cycle of all co-emitted species, which are not treated in this study.

\section{Methods}

[5] A series of equilibrium climate simulations are conducted with the National Center for Atmospheric Research (NCAR) CESM version 1.0.3 [Gent et al., 2011], consisting of the Community Atmosphere Model 4 (CAM4) coupled with the Community Land Model 4 (CLM4), sea-ice model CICE4, and a slab ocean model that facilitates fast equilibration. CAM4 is run at $1.9^{\circ} \times 2.5^{\circ}$ horizontal resolution with 26 vertical layers extending to about 2 mbar, represented with a hybrid sigma pressure coordinate. All analyses are performed on the final 20 years of 40 year simulations, during which climate equilibrium to the different forcings had been reached.

[6] A control simulation is run with no $\mathrm{BC}$ in the global atmosphere or snowpack. The first group of idealized experiments prescribes spatially uniform masses of BC at different altitudes and seasons in the Arctic atmosphere and Arctic snowpack and sea ice. Mass concentrations of hydrophilic $\mathrm{BC}$ are fixed to achieve a desired aerosol absorption optical depth (AAOD), defined in the CAM4 visible band $(0.35-0.64 \mu \mathrm{m})$. Establishing AAOD via hydrophilic BC is somewhat arbitrary but has very little bearing on the results. The first set of simulations in this group applies a seasonally constant AAOD of 0.005 within a single snow or atmospheric layer, defined in terms of its mid-layer pressure, while the second set applies an AAOD of 0.010 that operates only during select months and is distributed evenly in the lowermost seven atmospheric layers (extending from the surface to about $550 \mathrm{mbar}$ ) or surface snow. Seasons considered in this set of experiments are April-May,
June-July, and August-September, with winter months excluded because polar insolation and $\mathrm{BC}$ forcings are very small. The AAODs prescribed in these two sets of experiments were chosen to achieve Arctic radiative forcings on the order of $1 \mathrm{~W} \mathrm{~m}^{-2}$, subjectively deemed to be large enough to produce significant local climate signals without greatly exceeding present-day burdens and therefore triggering nonlinear climate feedbacks. A global forcing of this magnitude would increase global surface temperature by about $0.8 \mathrm{~K}$ (assuming a central estimate of climate sensitivity), or roughly double the interannual variability in model Arctic surface temperature. Observed monthly mean AODs at six sites in the Arctic range from 0.05 to 0.20 [Tomasi et al., 2007; von Hardenberg et al., 2012], and measurements of Arctic aerosol single-scatter albedo in the mid-visible spectrum range from 0.90 to 0.99 [e.g., Quinn et al., 2002; Brock et al., 2011; McNaughton et al., 2011], implying a range in Arctic AAOD of 0.0005-0.02. In experiments with BC in snow and sea ice, the AAOD was applied uniformly in the top layer of snow on land ( $2 \mathrm{~cm}$ thick), snow on sea ice (up to $4 \mathrm{~cm}$ thick), and surface scattering layer of snow-free sea ice (up to $5 \mathrm{~cm}$ thick). Because snow and sea ice only partially cover the Arctic, some fixed AAOD experiments applied two or threefold greater AAOD in snow and sea ice to achieve larger radiative forcings and are labeled accordingly in results with " $2 \times$ " or " $3 \times$." The presence of non-BC absorbing matter such as soil dust decreases the impact of BC on snow albedo [e.g., Doherty et al., 2010], and hence these experiments can be considered general sensitivity studies on the climate effects of altered solar energy absorption in the Arctic environment.

[7] The second group of experiments applies BC emissions that are transported and deposited using the CAM4 bulk aerosol model [e.g., Rasch et al., 2000; Collins et al., 2004]. In different experiments, the prognostic BC is allowed to operate radiatively only within certain combinations of the Arctic (defined here as $60-90^{\circ} \mathrm{N}$ ) and extraArctic atmosphere and snow + sea ice. These simulations apply year 2000 BC emissions [Lamarque et al., 2010], scaled by a factor of 2 to achieve an Arctic forcing that, operating in isolation, can produce a significant local climate response. As a result, global $\mathrm{BC}$ emissions are $15.5 \mathrm{Tg} \mathrm{yr}^{-1}$, of which $12.7 \%$ and $1.2 \%$ originate from latitudes north of $60^{\circ} \mathrm{N}$ and $66^{\circ} \mathrm{N}$, respectively. Arctic shipping sources are not included in this inventory.

[8] Nine externally mixed aerosol species are carried in the CAM4 bulk scheme. BC and organic carbon are emitted as hydrophobic species that transform into respective hydrophilic species with an $e$-folding time of 1.2 days. Sulfur dioxide emissions oxidize into sulfate at rates that depend on prescribed oxidant fields generated with an offline chemical transport model. Prognostic emissions of mineral dust depend on surface wind, soil, and vegetation characteristics, and are transported in four size bins. Previous literature describes the advection and radiative treatment of deposited BC and dust in the land snow [Flanner et al., 2007; Oleson et al., 2010; Lawrence et al., 2011] and sea ice [Briegleb and Light, 2007; Holland et al., 2012] components of CESM. All aerosols are radiatively active in these simulations, with only BC forcing manually altered between experiments. CAM4 uses a bulk microphysical scheme to prognose cloud condensate mass [Rasch and 
Kristjánsson, 1998], but not size distribution, and therefore the cloud albedo and lifetime indirect effects are not treated in this study. More sophisticated representations of aerosol mixing, aerosol-cloud interactions, and aerosol deposition have recently been incorporated into CAM5, producing much less BC in the Arctic atmosphere than in CAM4 and observations [e.g., Liu et al., 2012]. Simulated Arctic BC, however, is quite sensitive to uncertain model parameters governing wet removal efficiency [e.g, Browse et al., 2012; Zhou et al., 2012]. Because of uncertainties in actual BC forcing and the emphasis of this study on Arctic climate response to idealized forcings, temperature sensitivities normalized to forcing or mass are generally reported rather than absolute temperature changes. CAM4 simulates too little total Arctic cloud cover relative to satellite and groundbased observations, although mid-summer low cloud cover is slightly overestimated [de Boer et al., 2012; Kay et al., 2012b]. Like most models, CAM4 also simulates higher stability in the Arctic lower troposphere than represented in re-analysis data [Medeiros et al., 2011; de Boer et al., 2012]. Observed and modeled vertical profiles of Arctic BC are discussed in the results (section 3.3).

[9] Top-of-atmosphere and surface direct radiative forcings are calculated interactively in the model each time step as the difference in absorbed solar energy flux with and without $\mathrm{BC}$, and means of these instantaneous quantities are reported. Atmospheric moist static energy $\left(E_{\mathrm{atm}}\right)$ is quantified using the vertical integral (from surface pressure $p_{s}$ to model top) of monthly mean output as

$$
E_{\mathrm{atm}}=\frac{1}{g} \int_{p_{s}}^{\mathrm{top}}\left[T(p) c_{p}+q(p) L_{v}+z(p) g\right] d p
$$

where $T, q$, and $z$ are, respectively, the vertically dependent temperature, specific humidity, and geopotential height, and $c_{p}$ and $L_{v}$ are, respectively, the specific heat capacity of dry air and latent heat of fusion of water. Mass concentrations (densities) of BC, cloud condensate, and water vapor are calculated from mass mixing ratios and ambient (monthly mean) pressure and temperature in each grid cell. Net meridional energy transport into the Arctic is inferred as the annual mean imbalance of top-of-atmosphere net radiation integrated over the Arctic [e.g., Peixóto and Oort, 1992]. Because Q-fluxes are fixed in the slab ocean model, all changes in meridional energy transport originate from atmospheric processes, which dominate poleward heat flux at $60^{\circ} \mathrm{N}$ [Trenberth and Caron, 2001]. Some results from the Arctic fixed AAOD experiments are reported in terms of a BC mass-normalized temperature sensitivity, with units of $\mathrm{K}(\mathrm{Gg} \mathrm{yr})^{-1}$. This represents the Arctic equilibrium surface temperature response normalized to a mass of BC operating during the entire year (and every year). For example, the sensitivity associated with Arctic annual mean warming of $2 \mathrm{~K}$ in response to a $\mathrm{BC}$ mass of $1 \mathrm{Gg}$ residing for 1 month each year in the Arctic atmosphere would be $24 \mathrm{~K}(\mathrm{Gg} \mathrm{yr})^{-1}$. For snow and sea-ice forcings, this value depends on the area of cryospheric cover. The mass of $\mathrm{BC}$ is derived from the prescribed AAOD of hydrophilic BC and its mass absorption cross-section, which is $12.5 \mathrm{~m}^{2} \mathrm{~g}^{-1}$ in the CAM4 visible band and $11.1 \mathrm{~m}^{2} \mathrm{~g}^{-1}$ at $550 \mathrm{~nm}$. These optical properties were applied previously [Flanner et al., 2009], and one could easily scale the mass-normalized temperature sensitivities reported here according to alternative $\mathrm{BC}$ absorption properties. One could also assume atmospheric and surface snow BC residence times to translate these sensitivities into annual emissions-normalized quantities. Finally, statistical significance of climate changes in each experiment, relative to the control simulation, are computed using pooled $t$-tests with 20 annual realizations from each equilibrium state.

\section{Results and Discussion}

\subsection{Altitudinally Varying Arctic Forcing}

[10] Table 1 presents results from the fixed AAOD group of idealized experiments, including Arctic annual mean radiative forcings, equilibrium changes in surface temperature and energy fluxes, and sensitivities. As expected, the TOA radiative forcing is positive in all cases, while the instantaneous surface radiative forcing is negative for all atmospheric cases because of surface dimming, and positive for all snow/ice cases because of surface darkening. TOA forcing increases substantially with increasing BC altitude, but the spread in surface forcing is quite narrow. This occurs because (1) most of the additional absorption with increasing $\mathrm{BC}$ altitude is from above-cloud BC, (2) the Arctic surface is reflective, contributing to small surface forcings that change little with changing downwelling flux, and (3) the equilibrium surface albedo is slightly darker with lower altitude BC because of cryospheric changes described later. Total Arctic atmospheric moist static energy increases in all cases, also expected from direct heating of the troposphere or surface. In all cases except one, this atmospheric heating reduces net meridional energy transport into the Arctic.

[11] The surface temperature response, however, varies considerably with the altitude of solar heating. Forcing exerted in the atmospheric layer centered at 227 mbar, spanning 210-246 mbar, causes surface cooling, while forcings exerted at 434 and 697 mbar (layers spanning about 400-470 mbar and 650-750 mbar) produce either insignificant or weak surface warmings and sensitivities (Table 1). Strong warming results from near-surface atmospheric and within-snow/ice $\mathrm{BC}$, with sensitivity peaking at $2.8 \mathrm{~K}\left(\mathrm{Wm}^{-2}\right)^{-1}$ and $0.11 \mathrm{~K}(\mathrm{Gg} \mathrm{yr})^{-1}$ for seasonally constant $\mathrm{BC}$ in the lowest atmospheric layer.

[12] Different surface temperature sensitivities with $\mathrm{BC}$ forcing altitude arise from unique Arctic conditions and changes in atmospheric stability, clouds, and surface albedo. Stable atmospheric conditions in the Arctic prevent efficient transfer of energy deposited at higher altitudes to the surface, which experiences reduced insolation from all atmospheric BC [e.g., MacCracken et al., 1986]. Diabatic heating aloft and reduced surface heating further increase stability and thus amplify this phenomenon. Figure 1 depicts the vertical and seasonal dependence of Arctic atmospheric and surface temperature change in these experiments. In all cases, strong atmospheric heating occurs during summer at the altitude of $\mathrm{BC}$ forcing, but this warming does not propagate to the surface when $\mathrm{BC}$ is located at 227 mbar and propagates only weakly to the surface in the $434 \mathrm{mbar}$ and $697 \mathrm{mbar}$ cases. When BC is located at $867 \mathrm{mbar}$ and $993 \mathrm{mbar}$, however, heating clearly propagates to the surface, which warms during all seasons (Figure 1). This surface warming triggers snow/ice 
Table 1. Results from Fixed Arctic Aerosol Absorption Optical Depth (AAOD) Experiments ${ }^{\mathrm{a}}$

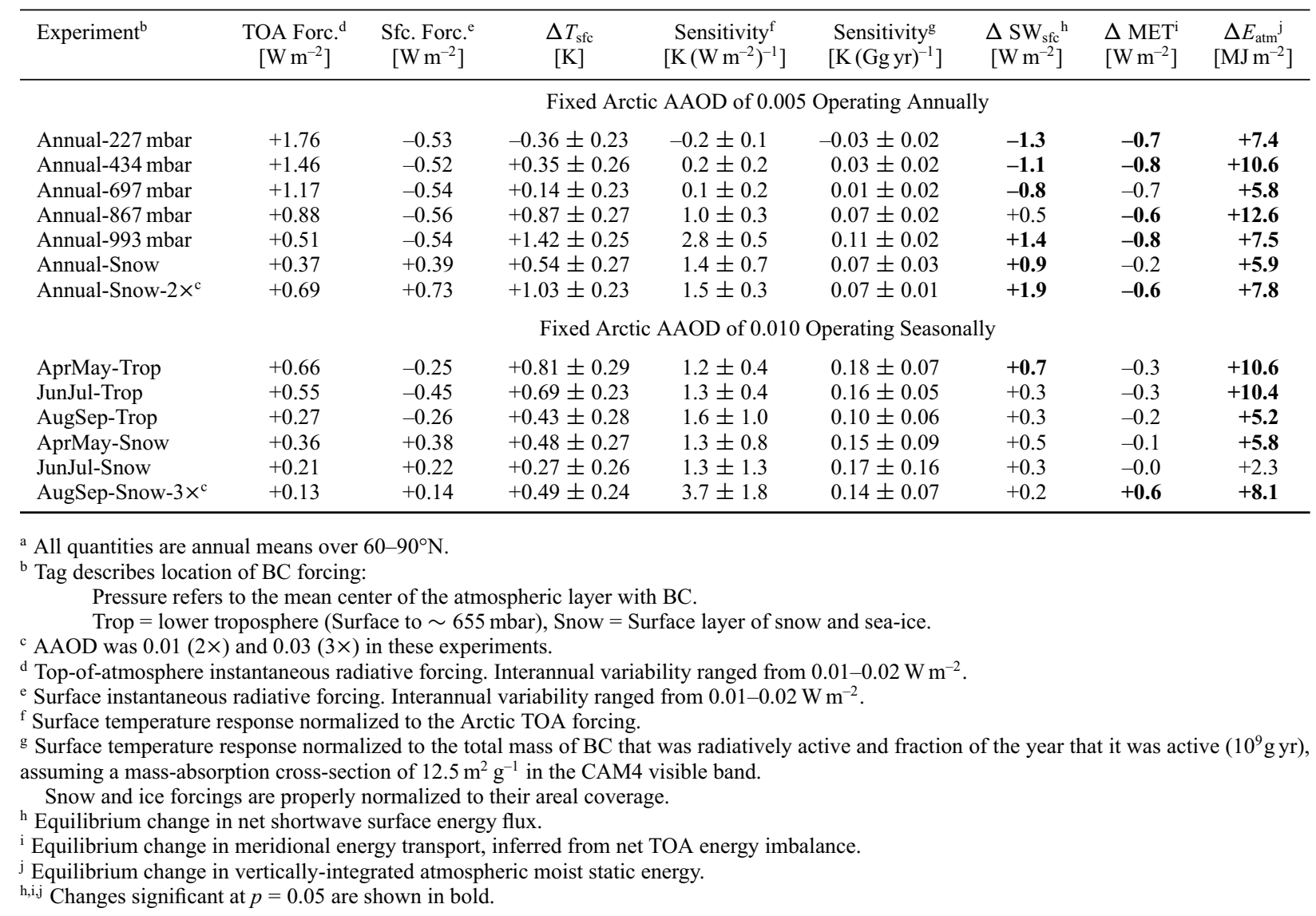

feedbacks which ultimately darken the surface, causing an increase in equilibrium surface solar energy absorption (Table 1), opposite of the change produced by BC forcing at altitudes of 697 mbar and above. This feedback-driven surface darkening (from lower altitude BC only) overwhelms the surface dimming from atmospheric extinction, and subsequent surface warming also overwhelms the cooling effect from decreased meridional energy transport into the Arctic. When $\mathrm{BC}$ is located only in the snow or sea ice, immediate heating occurs at the surface (i.e., positive surface forcing) and the equilibrium change in net surface solar flux is roughly twofold greater than the instantaneous surface forcing (Table 1). This demonstrates the amplifying effect of albedo change from (1) reduced cryospheric coverage and (2) darker cryospheric surfaces caused by thinning, more rapid snow metamorphism, and greater melt pond coverage. The early winter warming that occurs in some experiments (Figure 1) results primarily from sea-ice and water vapor responses and is discussed in section 3.4. Finally, because the altitudinal dependence of $\mathrm{BC}$ forcing efficacy hinges somewhat on the degree of atmospheric stability in the unforced state, it is worth noting again that this model simulates higher stability in the lower Arctic troposphere than shown in re-analysis data [Medeiros et al., 2011; de Boer et al., 2012].

[13] Decreasing efficacy (surface temperature response per unit radiative forcing) with increasing $\mathrm{BC}$ altitude is also found in model sensitivity studies with global BC located at different altitudes [Hansen et al., 1997, 2005; Ban-Weiss et al., 2011]. This is attributed largely to semi-direct cloud changes and the effectiveness through which higher-altitude diabatic heating can be dissipated through longwave emission to space [Hansen et al., 1997; Ban-Weiss et al., 2011]. Figure 2 shows changes in Arctic cloud content (liquid + ice) for the altitudinally varying fixed AAOD experiments. During the summer maximum in forcing, cloud content decreases within the layer of BC forcing, caused by decreased relative humidity from local heating [e.g., Ackerman et al., 2000; Cook and Highwood, 2004; Hansen et al., 2005]. With BC in the lowest atmospheric layer, this "burn-off" of summer low-lying clouds (Figure 2), which cool the Arctic surface during summer, helps explain amplified surface warming observed in the 993 mbar experiment. Surface heating also increases lapse rate and therefore decreases atmospheric stability. BC heating at higher altitudes, however, increases stability and inhibits convection at lower altitudes, therefore tending to increase cloud cover beneath the layer of heating through a "semi-direct" effect [e.g., Johnson et al., 2004; Hansen et al., 2005], as clearly occurs in the 434, 697, and 867 mbar experiments (Figure 2). This increase in low cloud cover decreases summer surface warming and helps explain the reduced temperature sensitivity to higher altitude BC (Table 1 and Figure 1). (Cloud increases during winter, however, warm the surface and are discussed later). These Arctic responses are generally consistent with cloud changes found in global 

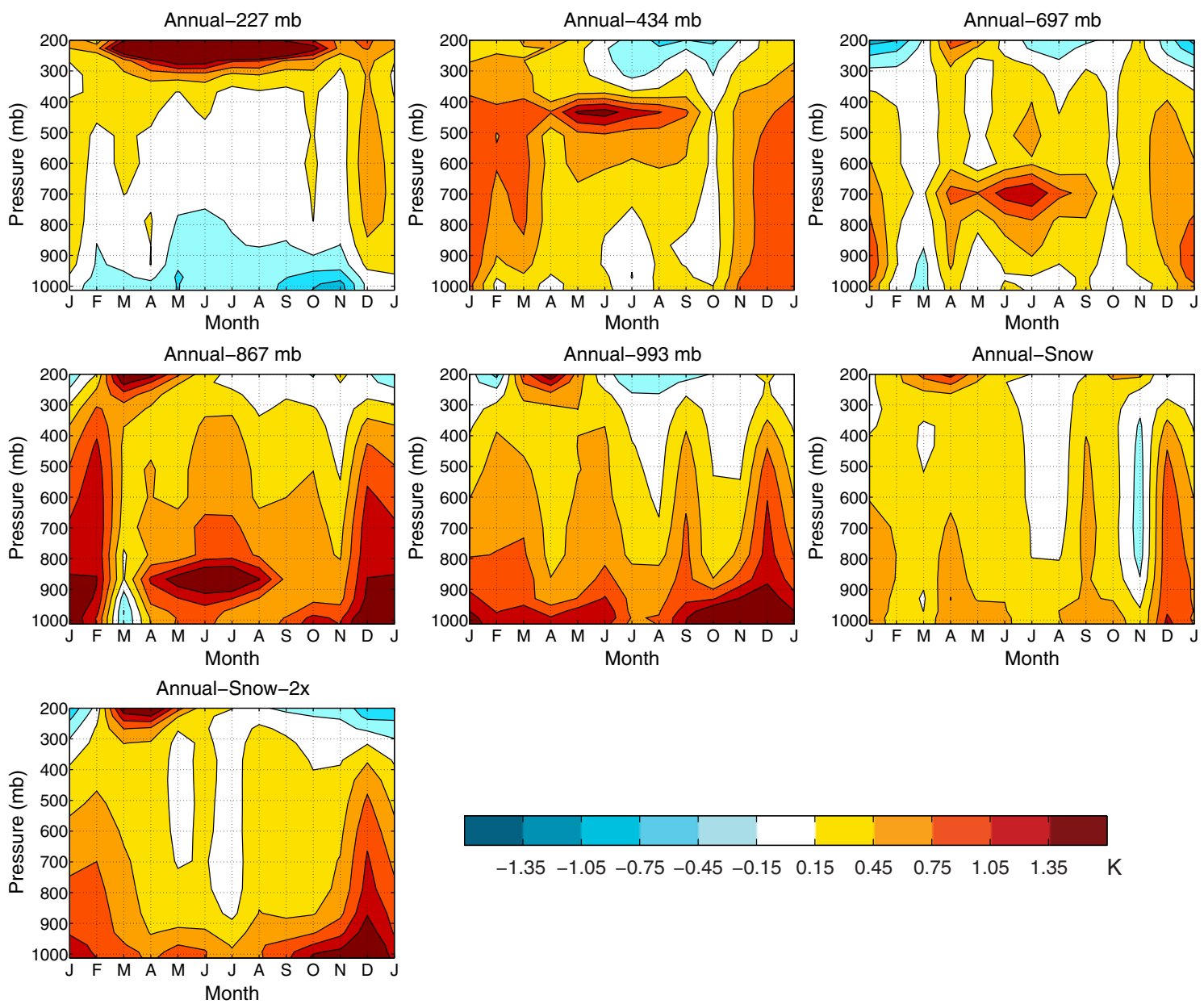

Figure 1. Equilibrium changes in Arctic $\left(60-90^{\circ} \mathrm{N}\right)$ atmospheric and surface air temperature with month and altitude for the first set of fixed AAOD experiments shown in Table 1. The vertical coordinate is hybrid sigma pressure used in CAM4.

sensitivity studies with prescribed absorption at different altitudes [Hansen et al., 2005; Ban-Weiss et al., 2011]. This study does not, however, treat aerosol-cloud indirect effects, which can warm the Arctic surface through longwave flux changes [Lubin and Vogelmann, 2006; Garrett and Zhao, 2006], cool the Arctic through shortwave flux changes [e.g., Alterskjor et al., 2010], and either amplify or reduce the global TOA flux perturbation from BC [Ming et al., 2010]. Arctic climate response to local $\mathrm{BC}$ changed relatively little, however, with inclusion of aerosol-cloud indirect effects in two other studies [Shindell and Faluvegi, 2009; Sand et al., 2013].

\subsection{Seasonally Varying Arctic Forcing}

[14] The seasonally dependent fixed AAOD experiments (Table 1, bottom), with BC distributed evenly between the surface and about 550 mbar, show that a unit mass of Arctic tropospheric $\mathrm{BC}$ tends to exert the largest TOA radiative forcing during April-May, rather than June-July when local insolation peaks. This is a consequence of higher underlying albedo during spring, caused by greater snow and sea-ice coverage and brighter snow and ice albedo during the pre-melt season [e.g., Perovich et al., 2002; Flanner et al., 2011]. Coverage of low clouds increases during the spring-summer progression in all model runs, contributing to increased TOA forcing from atmospheric BC [e.g., Penner et al., 1998; Haywood and Ramaswamy, 1998; Zarzycki and Bond, 2010] that partially offsets the influence of decreasing cryospheric cover. Surface forcing follows insolation more closely, becoming most negative during June-July. Opposite of TOA forcing, surface forcing from absorbing aerosols is weaker over reflective surfaces [e.g., Cess, 1983]. Arctic forcing from $\mathrm{BC}$ in the cryosphere also peaks during April-May because of expansive snow and sea-ice coverage, which reach annual minimums in August and September, respectively. Arctic annual mean surface albedo in the control simulation is 0.46 , peaking at 0.66 in March and reaching a minimum of 0.27 in August.

[15] Normalized to forcing, Arctic surface air warms the most from $\mathrm{BC}$ residing in snow and sea ice during AugustSeptember, which drives a very large sensitivity $[3.7 \pm$ $\left.1.8 \mathrm{~K}\left(\mathrm{Wm}^{-2}\right)^{-1}\right]$. Because of relatively small forcing in this experiment (caused by reduced late-summer insolation and minimal snow and sea-ice coverage), however, the variability in sensitivity is large and overlaps (within $1 \sigma$ ) with that of several other experiments (Table 1). This is also the sole experiment with Arctic-only BC to increase net meridional energy transport into the Arctic (Tables 1 and 2), 

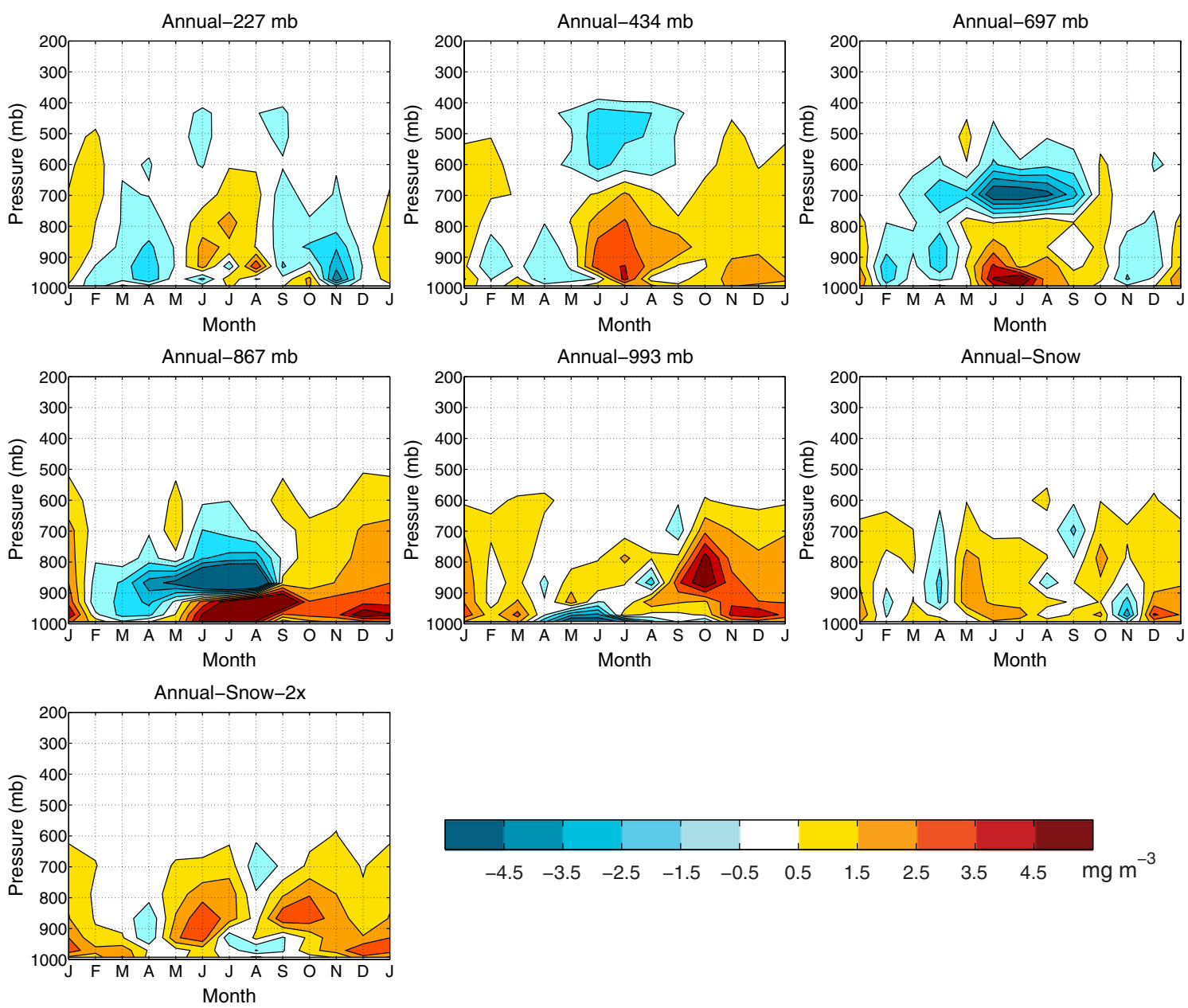

Figure 2. Equilibrium changes in Arctic $\left(60-90^{\circ} \mathrm{N}\right)$ cloud content (liquid+ice) with month and altitude for the first set of fixed AAOD experiments shown in Table 1. The vertical coordinate is hybrid sigma pressure used in CAM4.

Table 2. Arctic and Global Response to $2 \times$ Present-Day BC Emissions

\begin{tabular}{|c|c|c|c|c|c|c|c|c|}
\hline Experiment $^{\mathrm{a}}$ & $\begin{array}{l}\text { Arc. TOA Forc. } \\
\qquad\left[\mathrm{W} \mathrm{m}^{-2}\right]\end{array}$ & $\begin{array}{l}\text { Glb. TOA Forc. } \\
\qquad\left[\mathrm{W} \mathrm{m}^{-2}\right]\end{array}$ & $\begin{array}{l}\text { Arctic } \Delta T_{\text {sfc }} \\
{[\mathrm{K}]}\end{array}$ & $\begin{array}{c}\text { Arc. Sens. } \\
{\left[\mathrm{K}\left(\mathrm{W} \mathrm{m}^{-2}\right)^{-1}\right]}\end{array}$ & $\begin{array}{c}\text { Global } \Delta T_{\text {sfc }} \\
\text { [K] }\end{array}$ & $\begin{array}{c}\Delta \mathrm{SW}_{\text {sfc }^{\mathrm{b}}} \\
{\left[\mathrm{W} \mathrm{m}^{-2}\right]}\end{array}$ & $\begin{array}{l}\Delta \mathrm{MET}^{\mathrm{b}} \\
{\left[\mathrm{W} \mathrm{m}^{-2}\right]}\end{array}$ & $\begin{array}{c}\Delta E_{\mathrm{atm}}^{\mathrm{b}} \\
{\left[\mathrm{MJ} \mathrm{m}^{-2}\right]}\end{array}$ \\
\hline Arc:Atm & +0.58 & +0.04 & $-0.21 \pm 0.32$ & $-0.4 \pm 0.6$ & $-0.10 \pm 0.04$ & -0.8 & +0.0 & +3.5 \\
\hline Arc:Atm+Snow & +0.84 & +0.05 & $+0.38 \pm 0.31$ & $+0.5 \pm 0.4$ & $+0.05 \pm 0.04$ & +0.7 & -0.7 & +8.4 \\
\hline EArc:Atm & 0 & +0.62 & $+0.35 \pm 0.24$ & N/A & $+0.10 \pm 0.04$ & -0.3 & +0.7 & +5.5 \\
\hline EArc:Atm+Snow & 0 & +0.65 & $+0.55 \pm 0.32$ & N/A & $+0.21 \pm 0.05$ & +0.3 & +0.8 & +10.9 \\
\hline Glb:Atm+Snow & +0.86 & +0.70 & $+0.78 \pm 0.30$ & N/A & $+0.27 \pm 0.04$ & +0.5 & +0.1 & +12.8 \\
\hline
\end{tabular}

a Tag describes location of $\mathrm{BC}$ forcing: Arc $=60-90^{\circ} \mathrm{N}$; EArc $=-90-60^{\circ} \mathrm{N} ; \mathrm{Glb}=$ global; Atm $=$ atmosphere (evenly distributed from surface to $\sim 550 \mathrm{mbar}$ ); Snow = surface layer of snow and sea-ice.

$\mathrm{b}$ These quantities are averaged over the Arctic. Changes significant at $p=0.05$ are shown in bold.

offering one explanation for its large sensitivity. AugustSeptember is also the season of maximum sensitivity for the tropospheric BC cases. The timing of this peak is an expected consequence of reduced atmospheric stability during autumn [e.g., Kay and Gettelman, 2009], which facilitates more efficient surface-atmosphere energy exchange. Because of larger specific TOA forcing during spring, however, the largest mass-normalized surface temperature sensitivity occurs from April-May BC. The increase in forcing efficacy with summer progression offsets some of the reduction in forcing caused by decreasing insolation and albedo, reducing the seasonal spread in massnormalized sensitivity to a surprisingly narrow range $[0.10-$ $0.18 \mathrm{~K}(\mathrm{Gg} \mathrm{yr})^{-1}$, Table 1]. Forcings are generally small in these seasonally dependent experiments, however, and although all annual mean temperature changes are significant at $p=0.05$, changes in energy components are generally of comparable magnitude as the model interannual 
variability (Table 1), thus hindering interpretation of feedback processes.

\subsection{Response to Prognostic $\mathrm{BC}$ in the Arctic and Extra-Arctic Environments}

[16] In the second group of experiments, BC concentrations are prognosed throughout the atmosphere and snow (using doubled 2000 emissions), but are radiatively active only in different combinations of the Arctic and extra-Arctic atmosphere and snow (Table 2). Figure 3 shows the zonal mean vertical distribution of atmospheric BC simulated in the global experiment (Glb:Atm+Snow), and Figure 4 shows horizontal and vertical variability of Arctic BC. The Arctic annual mean AAOD is 0.0023 in this simulation, or about half that prescribed in the altitudinally varying fixed AAOD experiments. Table 2 summarizes the climate responses in these experiments, resulting from the convolution of $\mathrm{BC}$ forcing exerted at all altitudes and seasons. $\mathrm{BC}$ operating only in the Arctic atmosphere (experiment Arc:Atm) increases moist static energy of the Arctic atmosphere and reduces equilibrium net surface solar energy flux, similar to the higher-altitude fixed AAOD experiments, and causes a slight cooling of the Arctic surface (significant only at $p=0.20$ ). This experiment produces a local surface temperature change of $-0.21 \pm 0.32 \mathrm{~K}$, and is very similar in design to that conducted by Shindell and Faluvegi [2009] to produce the "BC" bar in Figures 1c and 1d of their paper, which shows a comparable sensitivity of about $-0.1 \mathrm{~K}\left(\mathrm{~W} \mathrm{~m}^{-2}\right)^{-1}$. Experiment Arc:Atm, conducted with a different climate model, therefore supports their finding that the current distribution of Arctic atmospheric BC, operating in isolation, causes weak cooling of the Arctic surface. This finding is also supported by a recent modeling study, conducted with the Norwegian Earth System Model (based largely on CESM), that finds Arctic cooling in response to Arctic atmospheric BC forcing scaled up by a factor 10 [Sand et al., 2013].

[17] Considered together with the fixed AAOD experiments at different altitudes, this result highlights the importance of the vertical distribution of Arctic BC. Figures 3

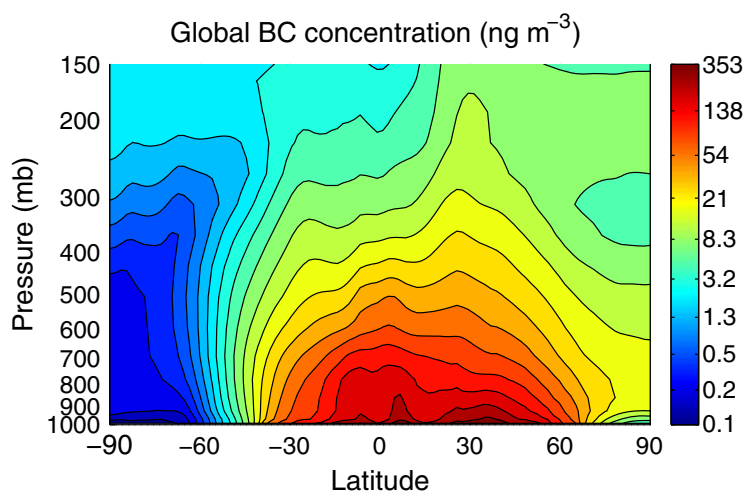

Figure 3. Annual, zonal mean black carbon concentration with latitude and altitude simulated in experiment Glb:Atm+Snow (Table 2), depicted on a logarithmic color scale. The vertical coordinate is hybrid sigma pressure used in CAM4. BC mixing ratios are converted to mass concentrations using ambient pressure and temperature. Global BC emissions in this simulation were $15.5 \mathrm{Tg} \mathrm{yr}^{-1}$. (a)
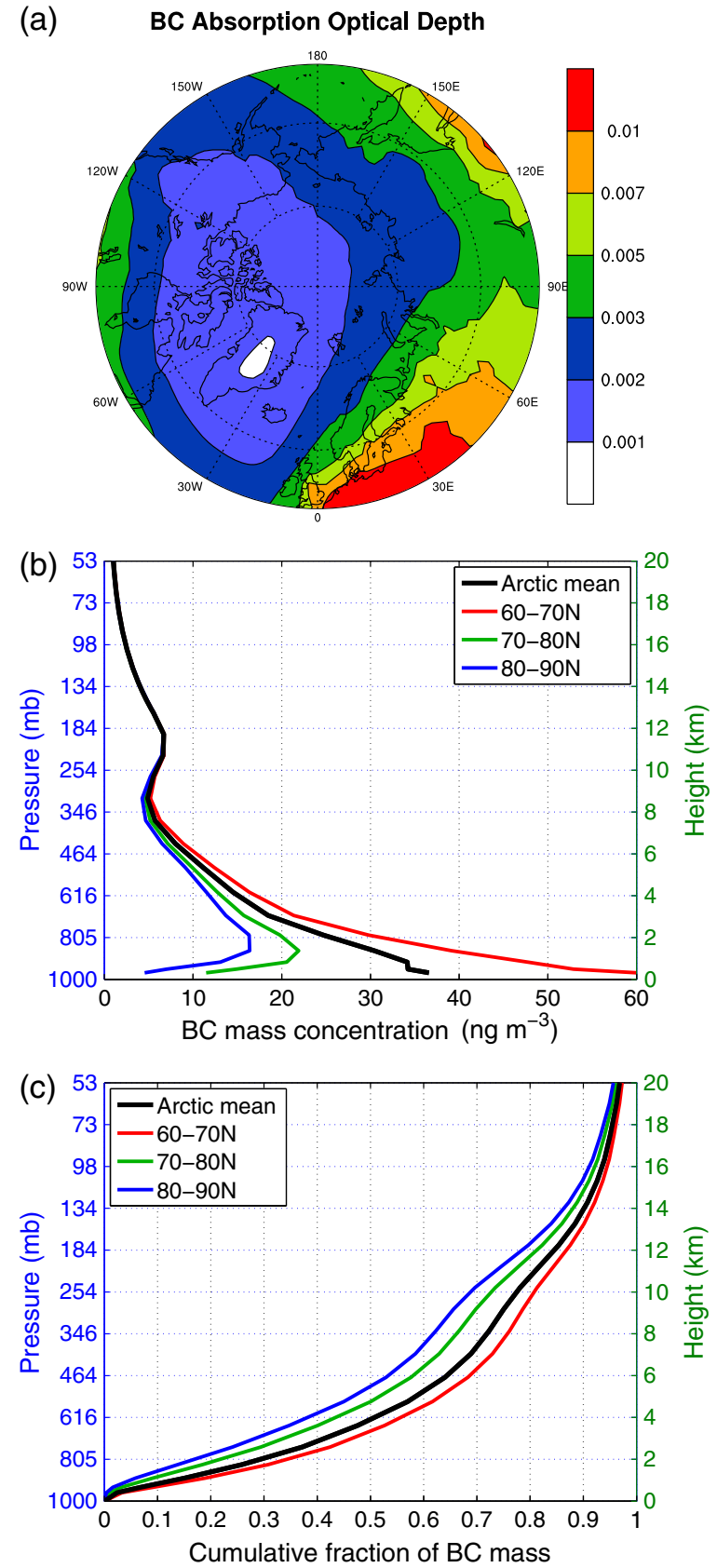

Figure 4. Annual mean Arctic black carbon simulated in experiment Glb:Atm+Snow (Table 2). (a) BC absorption optical depth in the CAM4 visible band $(0.35-$ $0.64 \mu \mathrm{m})$. (b) BC mass concentration with altitude, averaged over different latitude bands and the Arctic (60$90^{\circ} \mathrm{N}$ ) as a whole. (c) The fraction of total BC mass residing beneath the altitudes depicted on the vertical axes, averaged over different latitude bands (bottom). Values in the middle and bottom figures are plotted against mean geopotential height averaged over $60-90^{\circ} \mathrm{N}$ on the right axis, interpolated to the layer hybrid sigma pressures shown on the left axis. The top of the model is at about 2 mbar.

and 4 show that between $70-90^{\circ} \mathrm{N}$, simulated $\mathrm{BC}$ concentrations increase with altitude between the surface and about 850 mbar. Temperature profiles show an inversion layer 
extending to $850-900 \mathrm{mbar}$ at different Arctic latitudes, suggesting that $\mathrm{BC}$ becomes "trapped" above the boundary layer at these latitudes. This feature of the vertical BC profile has important implications for its local forcing efficacy because of the diminished warming or cooling caused by higher altitude BC (e.g., Table 1). Aircraft measurements also show increasing $\mathrm{BC}$ concentrations with altitude in the lower Arctic atmosphere during most flights in the spring and summer of 2008 [Koch et al., 2009b; Spackman et al., 2010; Brock et al., 2011], with some profiles peaking at an altitude of several kilometers. Measurements between $60-80^{\circ} \mathrm{N}$ during January 2009 , however, essentially show monotonically decreasing BC with altitude [Schwarz et al., 2010]. Mean BC concentrations measured in the Arctic boundary layer and free tropospheric "background haze" during the ARCPAC campaign were, respectively, 18 and $60 \mathrm{ng} \mathrm{m}^{-3}$ [Brock et al., 2011], slightly greater than simulated values shown in Figure 4 (which, again, were produced using Lamarque et al. [2010] emissions scaled by a factor of 2). In a multi-model assessment, Koch et al. [2009b] found that aerosol models generally under-predict Arctic tropospheric BC relative to these data, although the aircraft measurements span small temporal domains and may not be representative of the broader Arctic climatology. The CAM simulation evaluated by Koch et al. [2009b] shows about $2-5 \times$ less BC beneath 500 mbar than measurements. Here, $25 \%$ of the simulated annual mean Arctic BC burden resides beneath $830 \mathrm{mbar}$ (roughly $1.7 \mathrm{~km}$ ), half is beneath 625 mbar (roughly $4 \mathrm{~km}$ ), and $75 \%$ is beneath $290 \mathrm{mbar}$ (roughly $9.1 \mathrm{~km}$ ) (Figure 4c). Thus a substantial portion of the simulated $\mathrm{BC}$ resides in the upper Arctic atmosphere, where it causes surface cooling or weak warming because of surface dimming combined with little dynamical heat transfer to the surface and an increase in summer low clouds. $12 \%$ of the $\mathrm{BC}$ mass resides above 150 mbar, well within the Arctic stratosphere. Ban-Weiss et al. [2011] found a threshold roughly at the tropopause for global $\mathrm{BC}$ additions to warm or cool global surface temperature, consistent with studies of nuclear war that simulate surface cooling from stratospheric solar absorption by soot and dust [e.g., Turco et al., 1983; Robock et al., 2007].

[18] Several recent studies show that BC transport to the Arctic is sensitive to aerosol aging and wet removal processes [Koch et al., 2009b; Garrett et al., 2011; Liu et al., 2011, 2012; Browse et al., 2012]. It follows that the Arctic $\mathrm{BC}$ vertical distribution is also likely sensitive to these processes, which are represented rather simplistically in CAM4. Koch et al. [2009b] show a large inter-model spread not only in BC amounts, but also in the vertical profiles of Arctic BC, attributable to differences in model physics. Such differences may lead to large spread in Arctic surface climate sensitivity to $\mathrm{BC}$, although interestingly the CAM and GISS models analyzed by Koch et al. [2009b], similar to those used here and by Shindell and Faluvegi [2009], show very different $\mathrm{BC}$ profiles between the surface and $200 \mathrm{mbar}$, despite their similar surface temperature sensitivities to total Arctic atmospheric BC.

[19] When $2 \times$ present $\mathrm{BC}$ emissions operate in Arctic snow and sea ice as well as in the atmosphere (Experiment Arc:Atm+Snow), Arctic net TOA (surface) forcing of $+0.84(-0.03) \mathrm{W} \mathrm{m}^{-2}$ produces Arctic surface warming of $0.38 \mathrm{~K}$, yielding a forcing sensitivity of $0.5 \pm$
$0.4 \mathrm{~K}\left(\mathrm{~W} \mathrm{~m}^{-2}\right)^{-1}$ (Table 2). This sensitivity lies in between those produced by upper tropospheric (200-700 mbar) fixed AAOD BC and those resulting from lower tropospheric and cryospheric BC (Tables 1 and 2). It is slightly larger than the regional Arctic sensitivity of $\left.0.31 \mathrm{~K}(\mathrm{~W} \mathrm{~m})^{-2}\right)^{-1}$ applied by Shindell et al. [2012], derived as the mean of Arctic responses to local $\mathrm{CO}_{2}$ and sulfate forcing found by Shindell and Faluvegi [2009]. BC operating only in the extra-Arctic atmosphere (experiment EArc:Atm) warms the Arctic, and when BC also operates in extra-Arctic snowpack (experiment EArc:Atm+Snow), the Arctic surface warming roughly doubles to $0.21 \mathrm{~K}$. Arctic warming from extraArctic BC is caused partially by an increase in meridional energy transport into the Arctic (Table 2), which results from the increased latitudinal temperature gradient produced by $\mathrm{BC}$ heating of the extra-Arctic atmosphere. Finally, BC operating in the global atmosphere and snow (experiment Glb:Atm + Snow) causes the largest Arctic warming $(0.78 \pm$ $0.30 \mathrm{~K})$ of experiments shown in Table 2. Net poleward energy transport into the Arctic is virtually unchanged in this experiment, reflecting the more even latitudinal distribution of heating that occurs from global BC. Consequently the Arctic surface warms about twice as much as when a nearly identical forcing operates exclusively in the Arctic environment and decreases net heat flux into the Arctic by $0.7 \mathrm{~W} \mathrm{~m}^{-2}$ (experiment Arc:Atm+Snow).

\subsection{Winter Warming}

[20] One interesting feature seen in several experiments is large winter surface and tropospheric warming in the Arctic, sometimes exceeding the immediate warming produced at the location and time of peak BC forcing (e.g., Figure 1). BC direct solar forcing is negligible during polar winter, and thus the mechanisms of warming must involve dynamical response. Equilibrium Arctic changes for a subset of experiments exhibiting significant winter warming are shown in Table 3. Robust (significant at $p=0.05$ ) winter features seen in all cases include (1) increased atmospheric water vapor, (2) increased condensed water path resulting from increased cloud liquid water that exceeds decreased ice content, (3) increased surface downwelling longwave flux, (4) increased latent heat flux from the surface, and (5) decreased sea-ice coverage. These changes all point to local hydrological feedback that amplifies winter warming. The increase in surface downwelling longwave flux results from increased atmospheric water vapor and cloud water path, and also directly from atmospheric warming. Increased cloudiness during winter uniquely warms the Arctic surface because compensating shortwave cooling effects are absent. Increased surface evaporation results from reduced winter sea-ice coverage and a warmer atmosphere that equilibrates with more water vapor.

[21] Exploration of the seasonal evolution of anomalies provides some insight into how BC may trigger a winter response. Summer/autumn increases in low clouds extend to winter in the Annual-434mb and JunJul-Trop experiments (and also clearly in the Annual-867mb experiment), and somewhat in the Annual-993mb experiment, but not in the Annual-Snow-2×, AugSep-Snow-3×, or Glb:Atm+Snow cases (partially shown in Figure 2). Figures 5 and 6 show monthly changes in water vapor content and sea-ice area, respectively, for experiments shown in Table 3. Water vapor 
FLANNER: BLACK CARBON INFLUENCE ON ARCTIC CLIMATE

Table 3. Equilibrium Arctic $\left(60-90^{\circ} \mathrm{N}\right)$ Winter (December-February) Changes from Select Experiments

\begin{tabular}{|c|c|c|c|c|c|c|c|}
\hline Experiment & $\begin{array}{l}T_{\mathrm{sfc}} \\
{[\mathrm{K}]}\end{array}$ & $\begin{array}{l}\text { Col. wat. vap. } \\
\qquad\left[\mathrm{kg} \mathrm{m}^{-2}\right]\end{array}$ & $\begin{array}{l}\text { Cld LWP } \\
{\left[\mathrm{g} \mathrm{m}^{-2}\right]}\end{array}$ & $\begin{array}{l}\text { Cld IWP } \\
{\left[\mathrm{g} \mathrm{m}^{-2}\right]}\end{array}$ & $\begin{array}{c}\mathrm{LW}_{\mathrm{sfc}}^{\downarrow} \\
{\left[\mathrm{W} \mathrm{m}^{-2}\right]}\end{array}$ & $\begin{array}{l}\text { LHFLX } \\
{\left[\mathrm{W} \mathrm{m}^{-2}\right]}\end{array}$ & $\begin{array}{c}\text { Ice area } \\
{\left[10^{6} \mathrm{~km}^{2}\right]}\end{array}$ \\
\hline Annual-434mb & +0.6 & +0.3 & +4.7 & $-0.7^{*}$ & +3.2 & $+0.4^{*}$ & -0.21 \\
\hline Annual-993mb & +1.7 & +0.3 & +5.9 & $-0.4^{*}$ & +5.6 & +1.3 & -0.42 \\
\hline Annual-Snow-2x & +1.4 & +0.3 & +4.8 & $-0.5^{*}$ & +5.1 & +1.3 & -0.33 \\
\hline JunJul-Trop & +1.1 & +0.3 & +5.0 & $-0.6^{*}$ & +4.6 & +0.6 & -0.30 \\
\hline AugSep-Snow-3x & +1.0 & +0.3 & $+3.7^{*}$ & -1.1 & +4.3 & +0.7 & -0.25 \\
\hline Glb:Atm+Snow & +0.9 & +0.3 & $+4.7^{*}$ & -1.0 & +4.0 & +1.2 & -0.39 \\
\hline
\end{tabular}

Variables (left to right) are surface air temperature, column water vapor path, cloud liquid water path, cloud ice water path, downwelling surface longwave flux, net surface latent heat flux (defined as positive out of the surface), and sea-ice area.

These changes were not significant at the $p=0.05$ level.
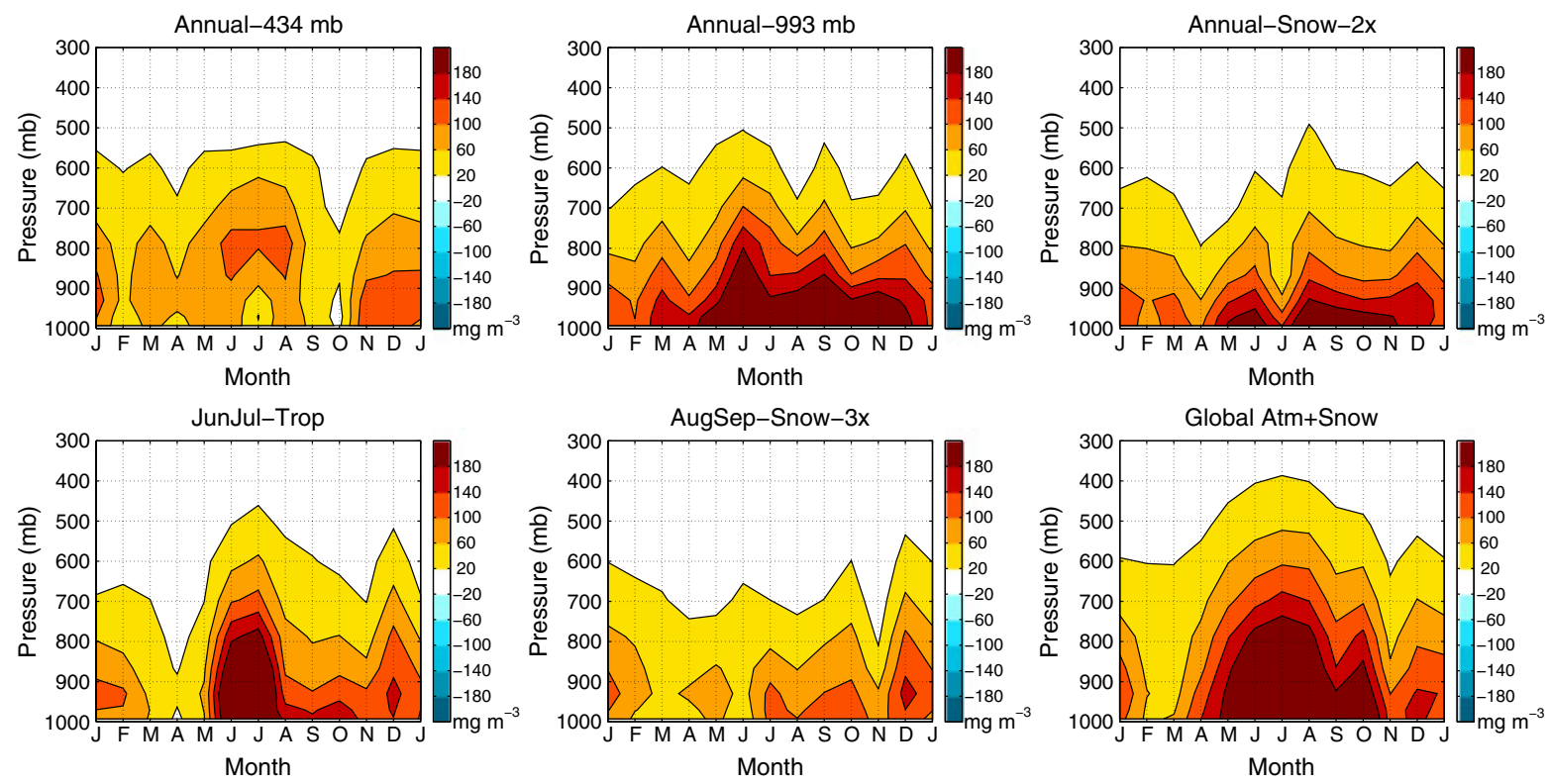

Figure 5. Equilibrium changes in Arctic $\left(60-90^{\circ} \mathrm{N}\right)$ atmospheric water vapor content with month and altitude for experiments shown in Table 3 . The vertical coordinate is hybrid sigma pressure used in CAM4.
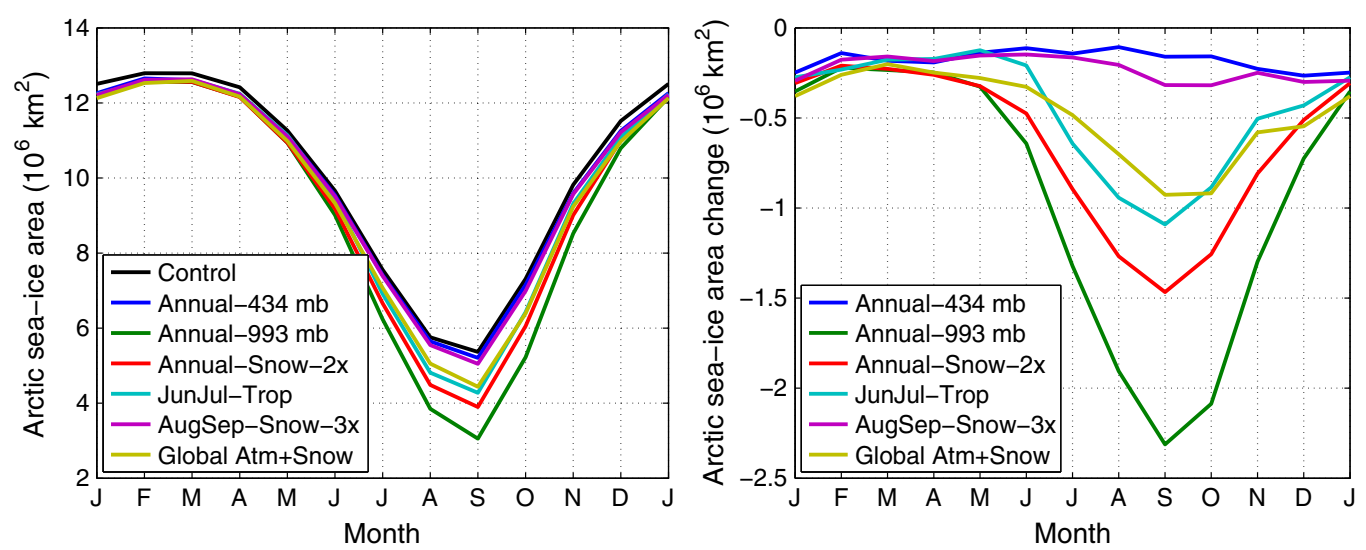

Figure 6. Seasonal cycle of equilibrium Arctic $\left(60-90^{\circ} \mathrm{N}\right)$ sea-ice area (left) and change in sea-ice area (right) for experiments shown in Table 3. 
anomalies are universally positive and generally continuous from summer to winter. The propagation of cloud and water vapor anomalies for several months following cessation of $\mathrm{BC}$ forcing requires coupling with features of the climate system that have longer response times, such as seaice coverage and ocean heat content. Annual-993mb and Annual-Snow- $2 \times$ forcings cause large reductions in autumn minimum sea-ice area (Figure 6). These anomalies extend to November and December, although sea-ice area largely recovers by January in all experiments, consistent with analysis showing that ice area anomalies have significant "memory" for only 2-5 months [Blanchard-Wrigglesworth et al., 2011]. (For reference, the 2.3 million $\mathrm{km}^{2}$ reduction in Arctic September sea-ice area that occurs in the Annual-993mb experiment is smaller than the observed decline in sea-ice extent of about 3 million $\mathrm{km}^{2}$ that has occurred since 1979.) Reduced autumn sea ice therefore appears to play a central role in early winter climate change within the Annual-993mb, Annual-Snow-2×, and JunJulTrop experiments (Figure 6), which all show peak winter warming in December, just before full winter ice recovery. Reduced autumn and winter sea ice is also evident in the Glb:Atm+Snow experiment, although this experiment includes extra-Arctic forcing and exhibits strong Arctic warming throughout the year (not shown). Autumn sea-ice loss is smaller in the Annual-434mb and AugSep-Snow-3× experiments. Poleward heat flux actually increased in the latter of these simulations (Table 1), likely contributing to the increase in winter atmospheric water vapor. Seasonal continuity in anomalies of one or more variables that can amplify winter surface warming, combined with decreased annual mean poleward energy transport in all Arctic forcing experiments except AugSep-Snow-3× (Tables 1 and 2), suggests that local feedbacks are primarily responsible for the winter warming in these experiments. Recently, Kay et al. [2012a] also concluded that local feedbacks cause most of the Arctic amplification from $\mathrm{CO}_{2}$ forcing in CAM4 and CAM5.

[22] As noted earlier, however, changes in ocean energy advection do not occur in the slab ocean model. Although the vast majority of poleward energy transport across $60^{\circ} \mathrm{N}$ occurs in the atmosphere [e.g., Trenberth and Caron, 2001], changes in meridional energy transport simulated here are only of order 1\%. Sand et al. [2013], applying the CAM4-Oslo atmospheric model coupled to a full ocean model, simulate a very different pattern of winter temperature change in response to large burdens of Arctic atmospheric BC, potentially indicating an important role for ocean-sea-ice dynamical coupling. The winter climate changes described here should therefore be interpreted with some caution.

[23] Together, Figures 1, 2, 5, and 6 show the potent influence of near-surface Arctic BC forcing in CAM4, exhibited in the Annual-993mb experiment. Summer "burnoff" of low clouds permits enhanced solar heating of the surface that decreases summer, autumn, and early-winter sea-ice coverage, leading to increased evaporation, atmospheric water vapor content, and low cloud cover during winter. These seasonal changes in low clouds, of opposite sign, both warm the Arctic surface, helping explain the very large temperature sensitivity exhibited by this experiment (Table 1).

\section{Conclusions}

[24] Idealized experiments have been conducted with the Community Earth System Model to elucidate how Arctic and global black carbon (BC) influence Arctic climate. These experiments show that the impact of Arctic $\mathrm{BC}$ on Arctic surface temperature depends strongly on the altitude of imposed forcing. BC in the lowest atmospheric layer causes very strong Arctic surface warming $\left[2.8 \mathrm{~K}\left(\mathrm{Wm}^{-2}\right)^{-1}\right.$ or $0.11 \mathrm{~K}(\mathrm{Gg} \mathrm{yr})^{-1}$ ] because of cloud and sea-ice feedbacks, with decreased summer low cloud cover and increased winter cloud cover both contributing to surface warming. Arctic BC in the mid-troposphere ( 400 - 750 mbar), however, causes weak warming, while $\mathrm{BC}$ at higher altitudes (230 mbar) cools the Arctic surface. This occurs because BC at higher altitudes decreases surface insolation and meridional energy transport into the Arctic, while increasing low cloud cover and atmospheric stability, thus inhibiting thermal mixing with the surface. The presentday distribution of Arctic atmospheric BC (simulated with doubled emissions), of which $30 \%$ resides above 400 mbar, slightly cools the Arctic surface, while extra-Arctic BC warms the Arctic by increasing poleward heat flux. These results support a previous study conducted with the climate model GISS-ER [Shindell and Faluvegi, 2009]. When BC deposition to Arctic snow and sea ice also affects climate, however, substantial local surface warming results, indicating that feedbacks triggered by surface heating outweigh the cooling effects of surface dimming and reduced meridional energy transport from atmospheric BC. Experiments exploring temperature sensitivities to Arctic BC operating seasonally show little variability in mass-normalized temperature response. This is a consequence of decreasing radiative forcing per unit mass with progression from May to September, but increasing forcing efficacy as the summer progresses, caused by decreasing atmospheric stability. Climate responses simulated here may be sensitive to model representations of boundary layer processes, aerosolcloud indirect effects, and ocean-sea-ice coupling, suggesting value in reproducing these experiments with other models. These idealized studies indicate that BC exposed to sunlight in the Arctic lower troposphere, snowpack, and sea ice causes large mass-normalized local surface warming. Sources of such BC include winter emissions that deposit to Arctic snow and ice and become exposed during the summer melt period. Additional studies quantifying transient climate response to changes in all co-emitted species associated with targeted mitigation measures [Shindell et al., 2012], and occurring at different locations and times, can help provide practical guidance to the broader community.

[25] Acknowledgments. This research was partially supported by NSF ATM- 0852775 and ARC-1023387. The author thanks three anonymous reviewers for their time and helpful comments.

\section{References}

Ackerman, A. S., O. B. Toon, D. E. Stevens, A. J. Heymsfield, V. Ramanathan, and E. J. Welton (2000), Reduction of tropical cloudiness by soot, Science, 288, 1042-1047.

Alterskjær, K., J. E. Kristjánsson, and C. Hoose (2010), Do anthropogenic aerosols enhance or suppress the surface cloud forcing in the Arctic? J. Geophys. Res, 115, D22204, doi:10.1029/2010JD014015. 
Ban-Weiss, G. A., L. Cao, G. Bala, and K. Caldeira (2011), Dependence of climate forcing and response on the altitude of black carbon aerosols, Clim. Dynam., 38, 897-911, doi:10.1007/s00382-011-1052-y.

Blanchard-Wrigglesworth, E., K. C. Armour, C. M. Bitz, and E. DeWeaver (2011), Persistence and inherent predictability of Arctic sea ice in a GCM ensemble and observations, J. Climate, 24 (1), 231-250, doi:10.1175/2010JCLI3775.1.

Bond, T. C., C. Zarzycki, M. G. Flanner, and D. M. Koch (2011), Quantifying immediate radiative forcing by black carbon and organic matter with the specific forcing pulse, Atmos. Chem. Phys., 11(4), 1505-1525, doi:10.5194/acp-11-1505-2011.

Briegleb, B. P., and B. Light, (2007), A Delta-Eddington multiple scattering parameterization for solar radiation in the sea ice component of the Community Climate System Model, Tech. Rep. NCAR/TN-472+STR, National Center for Atmospheric Research.

Brock, C. A., et al. (2011), Characteristics, sources, and transport of aerosols measured in spring 2008 during the aerosol, radiation, and cloud processes affecting Arctic Climate (ARCPAC) Project, Atmos. Chem. Phys., 11(6), 2423-2453, doi:10.5194/acp-11-2423-2011.

Browse, J., K. S. Carslaw, S. R. Arnold, K. Pringle, and O. Boucher (2012), The scavenging processes controlling the seasonal cycle in Arctic sulphate and black carbon aerosol, Atmos. Chem. Phys., 12(15), 6775-6798, doi:10.5194/acp-12-6775-2012.

Cess, R. D. (1983), Arctic aerosols: Model estimates of interactive influences upon the surface-atmosphere clear-sky radiation budget, Atmos. Environ., 17(12), 2555-2564.

Collins, W. D., P. J. Rasch, B. A. Boville, J. J. Hack, J. R. McCaa, D. L. Williamson, J. T. Kiehl, and B. Briegleb, (2004), Description of the NCAR Community Atmosphere Model (CAM 3.0), Tech. Rep. $N C A R / T N-464+S T R$, National Center for Atmospheric Research.

Cook, J., and E. J. Highwood (2004), Climate response to tropospheric absorbing aerosols in an intermediate general-circulation model, $Q . J . R$. Meteorol. Soc., 130, 175-191.

Corbett, J. J., D. A. Lack, J. J. Winebrake, S. Harder, J. A. Silberman, and M. Gold (2010), Arctic shipping emissions, inventories and future scenarios, Atmos. Chem. Phys., 10(19), 9689-9704, doi:10.5194/acp-109689-2010.

de Boer, G., W. Chapman, J. E. Kay, B. Medeiros, M. D. Shupe, S Vavrus, and J. Walsh (2012), A characterization of the present-day Arctic atmosphere in CCSM4, J. Climate, 25(8), 2676-2695, doi:10.1175/JCLID-11-00228.1.

Doherty, S. J., S. G. Warren, T. C. Grenfell, A. D. Clarke, and R. E. Brandt (2010), Light-absorbing impurities in arctic snow, Atmos. Chem. Phys., $10(23), 11,647-11,680$, doi:10.5194/acp-10-11647-2010.

Eleftheriadis, K., S. Vratolis, and S. Nyeki (2009), Aerosol black carbon in the European Arctic: Measurements at Zeppelin station, Ny-Alesund, Svalbard from 1998-2007, Geophys. Res. Lett, 36, L02809, doi:10.1029/2008GL035741.

Flanner, M. G., C. S. Zender, J. T. Randerson, and P. J. Rasch (2007), Present day climate forcing and response from black carbon in snow, J. Geophys. Res., 112, D11202, doi:10.1029/2006JD008003.

Flanner, M. G., C. S. Zender, P. G. Hess, N. M. Mahowald, T. H. Painter, V. Ramanathan, and P. J. Rasch (2009), Springtime warming and reduced snow cover from carbonaceous particles, Atmos. Chem. Phys., 9(7), 2481-2497, doi: 10.5194/acp-9-2481-2009.

Flanner, M. G., K. M. Shell, M. Barlage, D. K. Perovich, and M. A. Tschudi (2011), Radiative forcing and albedo feedback from the Northern Hemisphere cryosphere between 1979 and 2008, Nat. Geosci., 4, 151-155, doi:10.1038/ngeo1062.

Forsström, S., J. Ström, C. A. Pedersen, E. Isaksson, and S. Gerland (2009), Elemental carbon distribution in Svalbard snow, J. Geophys. Res., 114, D19112, doi:10.1029/2008JD011480.

Garrett, T. J., and C. Zhao (2006), Increased Arctic cloud longwave emissivity associated with pollution from mid-latitudes, Nature, 440, 787-789, doi:10.1038/nature04636.

Garrett, T. J., S. Brattström, S. Sharma, D. E. Worthy, and P. Novelli (2011), The role of scavenging in the seasonal transport of black carbon and sulfate to the arctic, Geophys. Res. Lett., 38(16), L16805, doi:10.1029/2011GL048221.

Gent, P. R., et al. (2011), The community climate system model version 4 , J. Climate, 24, 4973-4991, doi:10.1175/2011JCLI4083.1.

Goldenson, N., S. J. Doherty, C. M. Bitz, M. M. Holland, B. Light, and A. J. Conley (2012), Arctic climate response to forcing from lightabsorbing particles in snow and sea ice in CESM, Atmos. Chem. Phys., 12(17), 7903-7920, doi:10.5194/acp-12-7903-2012.

Gong, S, T. Zhao, S. Sharma, D. Toom-Sauntry, D. Lavoué, X. Zhang, W. Leaitch, and L. Barrie (2010), Identification of trends and interannual variability of sulfate and black carbon in the Canadian High Arctic: 1981-2007, J. Geophys. Res., 115 (D7), D07,305, doi:10.1029/2009JD012943.
Hansen, J., and L. Nazarenko (2004), Soot climate forcing via snow and ice albedos, Proc. Natl. Acad. Sci., 101 (2), 423-428, doi: 10.1073/pnas.2237157100.

Hansen, J., M. Sato, and R. Ruedy (1997), Radiative forcing and climate response, J. Geophys. Res., 102, 6831-6864.

Hansen, J., et al. (2005), Efficacy of climate forcings, J. Geophys. Res., 110, D18104, doi:10.1029/2005JD005776.

Haywood, J. M., and V. Ramaswamy (1998), Global sensitivity studies of the direct radiative forcing due to anthropogenic sulfate and black carbon aerosols, J. Geophys. Res., 103(D6), 6043-6058.

Hegg, D. A., S. G. Warren, T. C. Grenfell, S. J. Doherty, T. V. Larson, and A. D. Clarke (2009), Source attribution of black carbon in Arctic snow, Environ. Sci. Technol., 43, 4016-4021, doi: 10.1021/es803623f.

Hirdman, D., J. F. Burkhart, H. Sodemann, S. Eckhardt, A. Jefferson, P. K. Quinn, S. Sharma, J. Ström, and A. Stohl (2010), Long-term trends of black carbon and sulphate aerosol in the arctic: Changes in atmospheric transport and source region emissions, Atmos. Chem. Phys., 10(19), 9351-9368, doi:10.5194/acp-10-9351-2010.

Holland, M., D. A. Bailey, B. P. Briegleb, B. Light, and E. Hunke (2012), Improved sea ice shortwave radiation physics in CCSM4: The impact of melt ponds and aerosols on Arctic sea ice, J. Climate, 25, 1413-1430, doi:10.1175/JCLI-D-11-00078.1.

Jacobson, M. Z. (2004), Climate response of fossil fuel and biofuel soot, accounting for soot's feedback to snow and sea ice albedo and emissivity, J. Geophys. Res., 109, D21201, doi:10.1029/2004JD004945.

Jacobson, M. Z. (2010), Short-term effects of controlling fossil-fuel soot, biofuel soot and gases, and methane on climate, arctic ice, and air pollution health, J. Geophys. Res., 115, D14209, doi:10.1029/2009JD013795.

Johnson, B. T., K. P. Shine, and P. M. Forster (2004), The semi-direct aerosol effect: Impact of absorbing aerosols on marine stratocumulus, Q. J. R. Meteorol. Soc., 130(599), 1407-1422, doi:10.1256/qj.03.61.

Kay, J. E., and A. Gettelman (2009), Cloud influence on and response to seasonal arctic sea ice loss, J. Geophys. Res., 114, D18204, doi:10.1029/2009JD011773

Kay, J. E., M. M. Holland, C. M. Bitz, E. Blanchard-Wrigglesworth, A. Gettelman, A. Conley, and D. Bailey (2012a), The influence of local feedbacks and northward heat transport on the equilibrium Arctic climate response to increased greenhouse gas forcing, J. Climate, 25, 5433-5450, doi:10.1175/JCLI-D-11-00622.1.

Kay, J. E., et al. (2012b), Exposing global cloud biases in the Community Atmosphere Model (CAM) using satellite observations and their corresponding instrument simulators, J. Climate, 25, 5190-5207, doi:10.1175/JCLI-D-11-00469.1.

Koch, D., and J. Hansen (2005), Distant origins of Arctic black carbon: A Goddard Institute for Space Studies Model E experiment, J. Geophys. Res., 110, D04204, doi:10.1029/2004JD005296.

Koch, D., T. C. Bond, D. Streets, N. Unger, and G. R. van der Werf (2007), Global impacts of aerosols from particular source regions and sectors, J. Geophys. Res., 112, D02205, doi:10.1029/2005JD007024.

Koch, D., S. Menon, A. D. Genio, R. Ruedy, I. Alienov, and G. A. Schmidt (2009a), Distinguishing aerosol impacts on climate over the past century, J. Climate, 22, 2659-2677, doi: 10.1175/2008JCLI2573.1.

Koch, D., et al. (2009b), Evaluation of black carbon estimations in global aerosol models, Atmos. Chem. Phys., 9(22), 9001-9026, doi:10.5194/acp9-9001-2009.

Lamarque, J.-F., et al. (2010), Historical (1850-2000) gridded anthropogenic and biomass burning emissions of reactive gases and aerosols: methodology and application, Atmos. Chem. Phys., 10(15), 7017-7039, doi:10.5194/acp-10-7017-2010.

Lawrence, D., et al. (2011), Parameterization improvements and functional and structural advances in version 4 of the community land model, J. Adv. Model. Earth Syst., 3(45), 1-27, doi:10.1029/JAMES.2011.3.45.

Liu, J., S. Fan, L. W. Horowitz, and H. Levy II (2011), Evaluation of factors controlling long-range transport of black carbon to the Arctic, J. Geophys. Res., 116(D4), D04307, doi:10.1029/2010JD015145.

Liu, X., et al. (2012), Toward a minimal representation of aerosols in climate models: Description and evaluation in the Community Atmosphere Model CAM5, Geosci. Model Dev., 5(3), 709-739, doi:10.5194/gmd-5709-2012.

Lubin, D., and A. M. Vogelmann (2006), A climatologically significant aerosol longwave indirect effect in the Arctic, Nature, 439(7075), 453-456, doi:10.1038/nature04449.

MacCracken, M. C., R. D. Cess, and G. L. Potter (1986), Climatic effects of anthropogenic Arctic aerosols: An illustration of climate feedback mechanisms with one-and two-dimensional climate models, J. Geophys. Res., 91(D13), 14,445-14,450.

McConnell, J. R., et al. (2007), 20th-century industrial black carbon emissions altered Arctic climate forcing, Science, 317, 1381-1384, doi: $10.1126 /$ science. 1144856 . 


\section{FLANNER: BLACK CARBON INFLUENCE ON ARCTIC CLIMATE}

McNaughton, C. S., et al. (2011), Absorbing aerosol in the troposphere of the Western Arctic during the 2008 ARCTAS/ARCPAC airborne field campaigns, Atmos. Chem. Phys., 11(15), 7561-7582, doi:10.5194/acp11-7561-2011.

Medeiros, B., C. Deser, R. A. Tomas, and J. E. Kay (2011), Arctic inversion strength in climate models, J. Climate, 24(17), 4733-4740, doi:10.1175/2011JCLI3968.1.

Ming, Y., V. Ramaswamy, and G. Persad (2010), Two opposing effects of absorbing aerosols on global-mean precipitation, Geophys. Res. Lett., 37, L13701, doi:10.1029/2010GL042895.

Oleson, K. W., et al., (2010), Technical description of version 4.0 of the Community Land Model (CLM), Tech. Rep. NCAR/TN-478+STR, National Center for Atmospheric Research.

Peixóto, J. P., and A. H. Oort (1992), Phys. Clim., 520 pp., American Institute of Physics, Melville, New York.

Penner, J. E., C. C. Chuang, and K. Grant (1998), Climate forcing by carbonaceous and sulfate aerosols, Climate Dyn., 14, 839-851.

Penner, J. E., S. Y. Zhang, and C. C. Chuang (2003), Soot and smoke aerosol may not warm climate, J. Geophys. Res., 108(D21, 4657), doi: 10.1029/2003JD003409.

Perovich, D. K., T. C. Grenfell, B. Light, and P. V. Hobbs (2002), Seasonal evolution of the albedo of multiyear Arctic sea ice, J. Geophys. Res., 107(C10), doi:10.1029/2000JC000438.

Quinn, P. K., T. L. Miller, T. S. Bates, J. A. Ogren, E. Andrews, and G. E. Shaw (2002), A 3-year record of simultaneously measured aerosol chemical and optical properties at Barrow, Alaska, J. Geophys. Res., 107(D11), 4130, doi:10.1029/2001JD001248.

Quinn, P. K., et al. (2008), Short-lived pollutants in the Arctic: Their climate impact and possible mitigation strategies, Atmos. Chem. Phys., 8 (6), 1723-1735, doi:10.5194/acp-8-1723-2008.

Rasch, P. J., and J. E. Kristjánsson (1998), A comparison of the CCM3 climate model using using diagnosed and predicted condensate parameterizations, J. Climate, 11, 1587-1614.

Rasch, P. J., M. C. Barth, J. T. Kiehl, S. E. Schwartz, and C. M. Benkovitz (2000), A description of the global sulfur cycle and its controlling processes in the National Center for Atmospheric Research Community Climate Model, J. Geophys. Res., 105, 1367-1385.

Reddy, M. S., and O. Boucher (2007), Climate impact of black carbon emitted from energy consumption in the world's regions, Geophys. Res. Lett., 34, L11802, doi:10.1029/2006GL028904.

Rinke, A., K. Dethloff, and M. Fortmann (2004), Regional climate effects of Arctic Haze, Geophys. Res. Lett., 31 (16), L16,202, doi: 10.1029/2004GL020318.

Robock, A., L. Oman, G. L. Stenchikov, O. B. Toon, C. Bardeen, and R. P. Turco (2007), Climatic consequences of regional nuclear conflicts, Atmos. Chem. Phys., 7, 2003-2012, doi: 10.5194/acp-7-20032007.

Robock, A., L. Oman, and G. L. Stenchikov (2008), Regional climate responses to geoengineering with tropical and Arctic SO2 injections, J. Geophys. Res., 113(D16), D16,101, doi:10.1029/2008JD010050.

Sand, M., T. K. Berntsen, J. E. Kay, J. F. Lamarque, Ø. Seland, and A. Kirkevåg (2013), The arctic response to remote and local forcing of black carbon, Atmos. Chem. Phys., 13(1), 211-224, doi: 10.5194/acp-13-2112013.

Schwarz, J. P., J. R. Spackman, R. Gao, L. A. Watts, P. Stier, M. Schulz, S. M. Davis, S. C. Wofsy, and D. W. Fahey (2010), Global-scale black carbon profiles observed in the remote atmosphere and compared to models, Geophys. Res. Lett., 37, L18812, doi:10.1029/2010GL044372.
Sharma, S., E. Andrews, L. A. Barrie, J. A. Ogren, and D. Lavoue (2006), Variations and sources of the equivalent black carbon in the high Arctic revealed by long term observations at Alert and Barrow: 1989-2003, J. Geophys. Res, 111, D14208, doi:10.1029/2005JD006581.

Shindell, D. (2007), Local and remote contributions to Arctic warming, Geophys. Res. Lett., 34, L14704, doi:10.1029/2007GL030221.

Shindell, D., and G. Faluvegi (2009), Climate response to regional radiative forcing during the twentieth century, Nature Geosci., 2, 294-300, doi:10.1038/ngeo473.

Shindell, D., et al. (2012), Simultaneously mitigating near-term climate change and improving human health and food security, Science, 335 (6065), 183-189, doi:10.1126/science.1210026.

Shindell, D. T., et al. (2008), A multi-model assessment of pollution transport to the Arctic, Atmos. Chem. Phys., 8, 5353-5372, doi: 10.5194/acp-8-5353-2008.

Skeie, R. B., T. Berntsen, G. Myhre, C. A. Pedersen, J. Ström, S. Gerland, and J. A. Ogren (2011), Black carbon in the atmosphere and snow, from pre-industrial times until present, Atmos. Chem. Phys., 11(14), 6809-6836, doi:10.5194/acp-11-6809-2011.

Spackman, J. R., et al. (2010), Aircraft observations of enhancement and depletion of black carbon mass in the springtime Arctic, Atmos. Chem. Phys., 10(19), 9667-9680, doi:10.5194/acp-10-9667-2010.

Stohl, A. (2006), Characteristics of atmospheric transport into the Arctic troposphere, J. Geophys. Res., 111, D11306, doi:10.1029/ 2005JD006888.

Stone, R. S., G. P. Anderson, E. P. Shettle, E. Andrews, K. Loukachine, E. G. Dutton, C. Schaaf, and M. O. Roman III (2008), Radiative impact of boreal smoke in the Arctic: Observed and modeled, J. Geophys. Res., 113, D14S16, doi:10.1029/2007JD009657.

Tomasi, C., et al. (2007), Aerosols in polar regions: A historical overview based on optical depth and in situ observations, J. Geophys. Res., 112 (D16), D16205, doi:10.1029/2007JD008432.

Trenberth, K. E., and J. M. Caron (2001), Estimates of meridional atmosphere and ocean heat transports, J. Climate, 14 (16), 3433-3443.

Turco, R. P., O. B. Toon, T. P. Ackerman, J. B. Pollack, and C. Sagan (1983), Nuclear winter: Global consequences of multple nuclear explosions, Science, 222(4630), 1283-1292.

von Hardenberg, J., L. Vozella, C. Tomasi, V. Vitale, A. Lupi, M. Mazzola, T. P. C. van Noije, A. Strunk, and A. Provenzale (2012), Aerosol optical depth over the Arctic: A comparison of ECHAM-HAM and TM5 with ground-based, satellite and reanalysis data, Atmos. Chem. Phys., 12(15), 6953-6967, doi:10.5194/acp-12-6953-2012.

Wang, Q., et al. (2011), Sources of carbonaceous aerosols and deposited black carbon in the Arctic in winter-spring: Implications for radiative forcing, Atmos. Chem. Phys., 11(23), 12,453-12,473, doi:10.5194/acp11-12453-2011.

Warneke, C., et al. (2010), An important contribution to springtime Arctic aerosol from biomass burning in Russia, Geophys. Res. Lett., 37(5), L01801, doi:10.1029/2009GL041816.

Zarzycki, C. M., and T. C. Bond (2010), How much can the vertical distribution of black carbon affect its global direct radiative forcing?, Geophys. Res. Lett., 37, L20807, doi:10.1029/2010GL044555.

Zhou, C., J. E. Penner, M. G. Flanner, M. M. Bisiaux, R. Edwards, and J. R. McConnell (2012), Transport of black carbon to polar regions: Sensitivity and forcing by black carbon, Geophys. Res. Lett., 39(22), L22804, doi:10.1029/2012GL053388. 